\title{
Organics Online: Turning Problems into Selling Points
}

\author{
Matthew G. Zebrowski ${ }^{1}$
}

This article describes the results of a visual and rhetorical analysis of images on food websites. The images are taken from the homepages of major North American food manufacturers and their organic subsidiaries, and are used to argue that organic food is often marketed in a way that aligns it with common critiques of the food industry. This article further argues that this marketing presents consumption of organic products as aligned with food activist values, which is especially disconcerting given the consolidated nature of the organic food industry. [Article copies available for a fee from The Transformative Studies Institute. E-mail address: journal@transformativestudies.org Website: http://www.transformativestudies.org (02014 by The Transformative Studies Institute. All rights reserved.]

KEYWORDS: Organic Food, Food Activism, Consumer Activism, Food Marketing, Epideictic Rhetoric, Visual Rhetoric.

\section{INTRODUCTION}

When I tell people about the consolidation of the organic food industry into "big food," they often seem surprised. I suspect their surprise is, in part, because this information is not particularly widely known (despite being a matter of public record, acquisitions are rarely publicized in company narratives or branding). More importantly, however, I believe it is also because organic food is often seen as ideologically antithetical to the aims of the food industry. In this article, I argue that this seemingly oppositional relationship is no accident. I use rhetorical theory and a visual analysis of food companies' websites to argue that organic

\footnotetext{
${ }^{1}$ Matthew G. Zebrowski is a Ph.D. candidate in English at Carnegie Mellon University, where he plans to defend his dissertation this academic year. His current research focuses on the rhetorical presentation of consumption as activism in food marketing. Address correspondence to: Matthew G. Zebrowski, Carnegie Mellon University, English Department; e-mail: mgz@andrew.cmu.edu. Acknowledgement: This article grew out of a research project conceived with Suguru Ishizaki to test the coding method he outlined in "Toward a Unified Theory of Visual-Verbal Strategies in Communication Design."
} 